\title{
The Borderlines of Aesthetics/Estetikens gränser
}

It is a well-known fact that as an academic discipline and also as an empirical subject, aesthetics has been subject to an intensive discussion throughout the historical lifetime of the concept. The relation to art already exemplifies this. To some traditions aesthetics is sheer philosophy of art (for example to Hegel and onwards) whereas to others the problems of art merely constitutes a subordinate province in the overall area. All things considered, aesthetics has intensive and often fruitful borderline problems in relation to philosophy in general, in relation to cultural theory, to psychology, and of course to the disciplines of the individual artforms (literature, visual arts etc.) which in their own areas are working with aesthetic problems.

The annual conference of the Nordic Society for Aesthetics was held at Aarhus University, Denmark 2003 (May 22-25), the theme being "The Borderlines of Aesthetics". Inspiring papers and fruitful discussions examined these problems from varying angles. This volume of The Nordic Journal of Aesthetics publishes a selection of the papers given on this occasion. MORTEN KYNDRUP 